\title{
Explaining the Disposition Bias among Investors: The Mediatory Role of Personality, Financial Literacy, Behavioral Bias and Risk Tolerance
}

\author{
Asad Basheer \\ Research Scholar, Karachi University Business School, University of Karachi, Pakistan \\ E-mail: asadbasheer02@gmail.com
}

Dr. Danish Ahmed Siddiqui

Associate Professor, Karachi University Business School, University of Karachi, Pakistan

E-mail: daanish79@hotmail.com

Received: April 12, 2020 Accepted: May 19, 2020 Published: May 27, 2020

doi:10.5296/ber.v10i2.16827ＵRL: https://doi.org/10.5296/ber.v10i2.16827

\begin{abstract}
Investors are frequently subjected to cognitive error. They often sell stocks that have increased in value, while keeping stocks that have dropped in value. We proposed a theoretical framework explaining what factors affect this disposition bias and how. According to the proposed theory, Disposition bias is affected through risk tolerance, financial literacy, and behavioural biases. Lower risk tolerance and low financial literacy can aggravate disposition bias. We also proposed that personality factors such as Superego, Parsimony, Orderliness, and Obstinacy also influences both the level of financial literacy as well as behavioural biases that in turn affect disposition bias. Empirical validity was established by conducted a survey using close ended questionnaire. Data was collected from 182 investors trading through 3 brokerage firms in Karachi. Confirmatory factor analysis and structured equation modelling were used for analysis. The results suggested that financial literacy significantly affect all behavioural biases (except Representativeness) as well as Disposition Bias. Higher financial literacy will tend to show less disposition bias and they better can make portfolio decision. Similarly, risk tolerance also affects disposition biases as a risk-averse investor will tend to show more disposition bias. Among the behavioural factors, Anchoring, overconfidence, and loss aversion affect disposition biases. Overconfidence also seems to affect risk tolerance. Personality traits like superego and parsimony seem to affect
\end{abstract}


almost all the behavioural biases. Similarly, superego and parsimony affect risk tolerance. Similarly, Superego and obstinacy affected financial literacy. This finding will help investors to better manage their portfolio by mitigating these biases.

Keywords: Disposition bias, Behavioural bias, Financial literacy, Risk tolerance, Investment decision, Herding behaviour

\section{Introduction}

\subsection{Background to the Study}

Decision making always remains as a complex process. Many factors involved in the decision-making process. When it comes to the stock market then it becomes even more complex because little delay results in huge losses. An investor spread his money in different funds \& stocks this involves many factors which could be financial knowledge, Cognitive \& behavioural biases, Sentiments \& demographics.

In Pakistan, investor's do influence their family, colleagues \& peer group when effect decision process. As the stock market usually based on speculation then being a financial literate, an investor can protect him from incurring losses because he understands the behaviour of the market. It is very common in investors that they sell shares when its price goes up \& hold when prices go down and this may not allow an investor to constitute an effective portfolio. Cognitive biases are another reason for the ineffective portfolio because of investor unable to see the correct picture of the market due to biases. Disposition bias also based on investor risk appetite; how much risk an investor can bear for a given level of return. Risk appetite varies from person to person, gender, age \& income level. Personality also plays a vital role in constituting a portfolio. Pakistan is a developing country; therefore, financial literacy becomes more important to make an effective portfolio with limited choices available. Investors can be at great risk when they are not financially literate \& enter into a contract with the service provider of financial markets.

\subsection{Problem Statement}

As most of the researches have been done on financial literacy, many of them suggest that investor's financial knowledge is far below from the needed level (Mouna\& Aziz, 2017). Changing in demographics, economic indicator, financial products it becomes crucial that investors should have some basic level financial literacy to understand and survive (Mouna \& Aziz, 2017). Lusardi \& Mitchell (2014) the rapid grow of complex financial products needs people to determine how much to keep in spare, invest so as not to outlast their benefits while addressing their needs, which expects family units to be well outfitted with financial knowledge.

Although, much literature has been written types of different assets are not directly associated with financial knowledge. To study about financial choices of households many kinds of literature are available but to restriction in trading data measurement of financial literacy becomes the toughest job for the researchers (Bailey et.al 2006). Investors with relatively high financial literacy \& with advance financial knowledge will go for a mutual fund in their 
portfolio according to many types of research. Overconfidence plays a role in choosing stocks $\&$ research suggests that overconfidence investors usually invest in stocks. Those who are less financial literate will tend to go toward advice to deal with complex financial products. Campbell (2006) according to financial theory, households do prefer to participate in equity market either directly or through a financial advisor. This behaviour most often leads to biases.

\subsection{Gap Analysis}

Mouna \& Anis (2015) researched sentiments of small investors, financial literacy \& stock returns. In this study, researcher focus was on cognitive errors that creates biases in decisions. Their focus was on small investors sentiments and its effect on investment on stock returns also, if experience can play a role in mitigating this. They conclude that investors with low level of knowledge and skills will be more likely to be influenced by behavioral bias. The study conducted in Tunisian context that they try to find out the relationship between financial literacy, cognitive biases, and stock returns. In Pakistan also researches conducted regarding to understand behavior pattern and investment decision when combine with financial literacy. Risk is used by most of the researchers because of its crucial role in investment. Awais, Laber, Raheed\& Khursheed (2016) researched to understand the role of financial literacy and investment experience with the mediating role of risk.

In the above-mentioned research, the focus was more on to gauge the risk if it could play a role when making decisions. Whereas study which conducted in Tunisian context gauge how cognitive errors combine with financial literacy affect investment experience. We combined financial literacy with investment experience and risk on investment decision.

The past researches on the disposition bias have been studied under the light of different variables like behavioral bias, demographic effect, sentiments of the investors, risk tolerance, ambiguity aversion etc. So, these variables have been utilized in our research and have helped us in reaching our goal. Unlike the other studies focusing on only one or two variables, this study has focused on many while studying the impact of those on the investor's disposition with the mediating effect of risk and personality.

We particularly focused on Disposition bias, and how it is affected through risk tolerance, financial literacy, and behavioral biases. We also included personality factors influences on both the level of financial literacy as well as behavioral biases that in turn affect disposition bias. To best of our knowledge, the effect of these combined factors on disposition biases was never studied before. Moreover, no such study was undertaken in Pakistan. It will add value as literacy rate in Pakistan considered being low and, therefore they display greater biases.

\subsection{Research Objectives}

The purpose of this study is to explore the relationship between behavioural bias, financial literacy, personality, risk tolerance $\&$ disposition bias and how these affect the portfolio of investors in the context of a developing country. It becomes more important when comes to a developing country, because of insufficient resources most people are not literate, especially in finance but they do investment. Therefore, they exhibit these biases on a greater extent. In 
this study, we specifically analysed that how investors with changes in personality trait, level of financial literacy, level of risk tolerance, and the presence of cognitive biases (Loss aversion, Anchoring, Overconfidence \& representativeness) will affect investment decision and ultimately result in disposition bias. And how this bias can be reduced to manage the portfolio.

\section{Literature Review}

(Chu \& Wang, 2017)Conducted study on financial literacy and wellbeing of an investor. They focus on how households' choices and returns differ with the level of financial literacy. The Return has taken as an indicator of financial wellbeing. The survey conducted in almost all the provinces of china and involves questions about assets and debt of households, income and expenditure, financial literacy \& financial planning. 3906 households participated in the survey from 25 provinces of mainland China. The study concludes that Households with a high level of financial literacy are more likely to engage in financial markets. They also found that households with greater financial literacy levels are more likely to hold mutual funds in their portfolios.

To study the financial literacy, risk attitude and saving motives of Indonesian investors concerning disposition bias Leon \& Pringganingrum (2018) conducted research. They aimed to investigate the impact of financial literacy, saving motives, risk on disposition bias of reksa dana investors of Indonesia who invest in Indonesian market. Reksa dana is an Indonesian word which mean is a mutual fund. Data was gathered through a questionnaire of 321 respondents. The data used in the research were analyzed through ordinal logistic regression. The finding of the study shows that disposition bias will be lower when investors financial knowledge higher whereas with low financial knowledge investors will show greater disposition bias. Shapira \& Venezia (2001) also found that for nonprofessional investors disposition impact will be higher than professional investors. Due to higher technical knowledge, high skills and experience than nonprofessional investors they tend to show lower biases. However, Jonsson et al (2017) found that Investors ' risk-taking attitude has no impact on bias although the investor is in the risk-seeking or avoiding group. This research was carried out for mutual fund investor's biases and financial literacy, (Kramer, 2016) Examine the relationship between financial literacy, confidence \& financial advice seeking. The sample size for this study consist of 1276 households from which financial advice seeking and financial literacy data was available. The result shows that the advice seeking tendency is remarkably similar for people who have high and low financial literacy. Somewhat $30 \%$ of households and investors of DHS sample show that Regardless of their level of assessed literacy, the primary source of advice should be professional financial advice. More confident investors seek less financial advice whereas no relationship observed between financial advice-seeking and financial literacy.

Mouna \& Anis (2015) conducted their study on the financial literacy of the Tunisian people. The results revealed that financial literacy and education of economics have a significant effect on the behaviour of investors. The lack of understanding of economics and finance is a strong deterrent to shareholdings and the lack of literacy has discouraged households from 
taking part in the stock market.

(Javed, Bagh, \& Razzak, 2017)Have studies herding effect, overconfidence \& representativeness in their study to know determinants of behaviour \& perceived investment performance in PSX known as Pakistan stock exchange. The study shows that overconfidence, representative, and herding bias have a positive impact on perceived investment performance\& strong correlation was found between the variables. Investment performance increased due to the overconfidence bias \& representativeness biases of the investor.

(Parveen \& siddiqui, 2018) Examine disposition effect, overconfidence bias, anchoring bias of Pakistan investors. Abnormalities were noted in investor behaviour when the global economy was disturbed by the 2008 financial crisis, which began in the US and resulted in a global recession (Parveen \& siddiqui, 2018). Investors use heuristics when they are faced with an intense situation in their financial decisions. The results suggested that Anchoring heuristic and disposition effect was found to highly significant and positively affecting the decision-making process of investors. Overconfidence found to be negatively related to decision making means that whenever investors will be overconfident, they may lose returns on their investment.

Masomi and Ghayekhloo (2011) study the behavioural impact of investors on decision making in the Tehran stock exchange. This study's results showed that behavioural factors manipulate investor decision-making. It was also found that the conduct of institutional investors trading in Tehran stock exchange was strongly influenced by heuristics such as anchoring and the fallacy of gamblers.

(Prosad, Kapoor, Sengupta, \& Roychoudhary, 2017)Carry out their study on disposition and overconfidence in the Indian equity market. It also detects growing bias has a greater impact in terms of trading volumes on the Indian equity market. (Prosad et al, 2017) also explored the area of behavioural finance in the Indian equity market. The data comprises of total daily returns and volume of transactions for each constituent stock and total index returns. Overall results show that both biases have a positive combined impact on the volume of transactions even after volatility control. The market-wide VAR results show that there is overconfidence that is consistent with the previous findings.

(Ahmad \& Maochun, 2019)Carry out a study to gauge the relationship between personality trait and investment decision using risk tolerance. Five personality traits namely extraversion, agreeableness, conscientiousness, neuroticism \& openness to experience were taken to study with biases herding behaviour, disposition, overconfidence, anchoring, \& representativeness in Pakistan. Data was collected from traders of Pakistan stock exchange who frequently trade. A negative correlation was found between disposition and risk tolerance whereas a significant effect was observed with personality traits and other behavioural biases. According to findings of the study individual with personality traits Conscientiousness, Neuroticism and openness to experience was found to be high risk-taker.

(Khan, 2017)Studies behavioural biases (Loss aversion \& availability biases) on decision 
making of investors using risk as a moderator. The sample was consisting of 260 questionnaires initially but those who responded were only 230. This study concludes that there is no significant difference between men and women decision-making responses concerning loss aversion bias. Just a few respondents were prone to risk tolerance bias and investment decision taking has a positive relationship. Most respondents were subject to bias in familiarity and the relationship between familiarity (availability) bias and investment decision making is weak. Risk perception moderation strengthens the relationship between loss aversion bias investment decisions while weakening the relationship between familiarity (availability) bias and investment decisions.

(Aren \& Zengin, 2016)Carry out a study on financial literacy and risk perception on investment choice of investors. People living in Istanbul were the respondent of the study. The data was collected through a survey method via email and in person. No relationship was found between personality traits and investment choice. Whereas it is found that investment choices vary with financial literacy and risk perception. It is found that the investor who is risk-takers will go for equity investment, foreign exchange \& portfolio. Whereas investors with low-risk propensity have deposits which they think can provide safe returns. They also observed that men are more financially literate than women when gauge advance financial literacy.

Jonsson et al (2017) conducted a study on mutual fund investor's disposition bias and financial literacy, saving motives, risk attitude. The research contains Swedish data which was collected through a survey in 2013 from 1564 households. The significant effect found in financial literacy on disposition bias.

(Sadi, Asl, Rostami, Gholipour, \& Gholipour, 2011)Conducted study on behavioural aspects of investor's, biases and investor's personality affect the financial decision. They conclude that there is a strong relationship between the personality of the investors and the perception errors in the stock market in Tehran and these findings are consistent with the research literature. The results show that there is a direct relationship between openness and insight and bias in confidence and a reverse relationship between bias in openness and availability. The results indicate that there is an inverse relationship between self-assuredness and randomness.

(Marcin, Adam, \& Monika, 2015)(Marcin, Adam, \& Monika, 2015) to investigate the degree of propensity to behavioural biases (the impact of certainty, the sunk cost fallacy, and mental accounting) among individuals with different levels of market investment expertise and to determine whether this susceptibility is associated with certain personality traits (impulsiveness, venturesomeness, and empathy). The research included 200 participants from the Warsaw Stock Exchange and 100 Warsaw School of Economics students who engage passively in the transaction. Results showed that behavioural bias sensitivity depends on the level of stock market investing knowledge. (Marcin et al, 2015) showed that Fine arts and music students were less vulnerable to over-confidence and more successful in predicting the likelihood of market events than a group of stock market traders and professional investors. 


\subsection{Hypotheses}

H1: Financial literacy has insignificant effect on Investor's disposition Bias.

H2: Behavioural Biases (overconfidence, Anchoring, Representativeness \& Loss aversion) has insignificant effect on Investor's disposition Bias.

H3: Risk Tolerance has insignificant effect on Investor's disposition Bias.

H4: Behavioural Bias (Over confidence, Anchoring, Representativeness \& Loss aversion) has insignificant effect on Investor's disposition Bias mediated by risk tolerance.

H5: Personality traits (Obstinacy, Orderliness, Parsimony \& Super ego) has insignificant effect on Investor's disposition Bias mediated by over confidence.

H6: Personality traits (Obstinacy, Orderliness, Parsimony \& Super ego) has insignificant effect on Investor's disposition Bias mediated by Anchoring.

H7: Personality traits (Obstinacy, Orderliness, Parsimony \& Super ego) has insignificant effect on Investor's disposition Bias mediated by Representativeness.

H8: Personality traits (Obstinacy, Orderliness, Parsimony \& Super ego) has insignificant effect on Investor's disposition Bias mediated by Loss aversion.

H9: Personality traits (Obstinacy, Orderliness, Parsimony \& Super ego) has insignificant effect on Investor's disposition Bias mediated by Financial literacy.

H10: Personality traits (Obstinacy, Orderliness, Parsimony \& Super ego) has insignificant effect on investor's disposition bias mediated by risk tolerance.

H11: Financial literacy has insignificant effect on Investor's disposition Bias mediated by risk tolerance.

H12: Financial literacy has insignificant effect on Investor's disposition Bias mediated by Personality traits (Obstinacy, Orderliness, Parsimony \& Super ego).

\section{Research Methods}

\section{Research Model:}

Disposition Bias $=\beta$ Loss aversion $+\beta$ Overconfidence $+\beta$ Representativeness $+\beta$ Anchoring $+\beta$ Financial literacy $+\beta$ Risk tolerance $+\beta$ Personality

Illustration of the model has been showed in figure 2

\subsection{Method of Data Collection}

Primary data collection method was effectively used which was the most appropriate method for collecting responses directly from our respondents. The primary data was collected through the participation of investors from different brokerage houses in Karachi. The purpose was to gauge their financial literacy \& biases. Also, to measure the level of risk they can bear. The target population was being explored by visiting individually and handing over 
the questionnaires personally.

\subsection{Sampling Technique}

In this research non-probability, convenience sampling technique was used. Because we accessed investors who were convenient to also reach brokerage house selected based on convenient to communicate and reach.

\subsection{Sample Size}

As per the supervisor's guidance and requirement of the research criteria the primary data was collected from the 182 respondents. The responses were collected from three brokerage house of Karachi. The responses were given anonymously by investors due to prevailing conditions in the country.

\subsection{Instrument of Data Collection}

The instrument used for collecting the primary data from our 182 respondents was a close-ended questionnaire. The questionnaire was adopted from previous studies. The questionnaires have 5 parts. The first part covers the financial literacy of investors. This adopted by Van Rooij et al. (2011a, b). 2nd part of the questionnaire covers risk tolerance (Mark M Kramer 2016). 3rd part of the questionnaire covers cognitive bias such as Anchoring, Overconfidence, Loss aversion \& Representativeness (Amari Mouna \& Jarboui Anis, 2015). The fourth part of the questionnaire covers personality such as orderliness, parsimony, obstinacy \& superego (Mudrack and Naughton (2004). Final part of the questionnaire covers disposition bias which is our dependent variable (Weber and Camerer, 1998). In Anchoring, Representativeness, Loss aversion \& overconfidence we used dichotomous scale which consist of answers Yes or No. For personality traits question dichotomous scale was used consist of Yes or No. For disposition bias we used a Likert scale ranging from not likely at all to highly likely I.e., 1 to 5. Likert scale was also used for risk tolerance ranging from strongly disagree to strongly agree. For financial literacy questions we used dichotomous \& multiple-choice. Question 1, 2,3,6,7,9,10 \& 11 consist of multiple choices. Whereas, question $4,5 \& 12$ consist of dichotomous.

\subsection{Statistical Technique}

The data collected through the questionnaire was pooled into Smart PLS. We used PLS regression by making a model estimate the relationship between the variable \& to check the outer loadings. To check the sig value PLS bootstrapping was used.

\subsubsection{Demographic Analyses}

The Total participants were 182 out in which 160 were males and 22 were females. Below table summarize the numbers. 
Table 1. Gender Classification

\begin{tabular}{|l|l|l|l|l|l|}
\hline & & Frequency & Percent & Valid Percent & Cumulative Percent \\
\hline \multirow{3}{*}{ Valid } & Male & 160 & 87.9 & 87.9 & 87.9 \\
\cline { 2 - 6 } & Female & 22 & 12.1 & 12.1 & 100.0 \\
\cline { 2 - 6 } & Total & 182 & 100.0 & 100.0 & \\
\hline
\end{tabular}

Table 1 summarize the Gender of participation. Only 22 were females whereas, 160 were males.

Taken together age with Gender, below table summarizes.

Table 2. Gender according to age

\begin{tabular}{|l|l|l|l|l|l|l|l|}
\hline & \multicolumn{5}{|l|}{ Age } & Total \\
\hline & & $16-24$ & $25-34$ & $35-45$ & $46-55$ & 55 onwards & \\
\hline Gender & Male & 16 & 39 & 62 & 41 & 2 & 160 \\
\hline & Female & 2 & 16 & 3 & 1 & 0 & 22 \\
\hline Total & & 18 & 55 & 65 & 42 & 2 & 182 \\
\hline
\end{tabular}

Table 2 summarizes the age group of respondents. We divide the age into 4 categories. Most of the investors were from age between 35 to 40 .

The Annual income of the participants is summarized below.

Table 3. Annual Income Level in Rupees

\begin{tabular}{|l|l|l|l|l|l|}
\hline & & Frequency & Percent & Valid Percent & Cumulative Percent \\
\hline Valid & less than 400,000 & 17 & 9.3 & 9.3 & 9.3 \\
\hline & $400,000-800,000$ & 44 & 24.2 & 24.2 & 33.5 \\
\hline & $800,000-1600,000$ & 117 & 64.3 & 64.3 & 97.8 \\
\hline & Greater than 1600,000 & 4 & 2.2 & 2.2 & 100.0 \\
\hline & Total & 182 & 100.0 & 100.0 & \\
\hline
\end{tabular}

We categorize the income level in four categories. Category 1 was for individual who has annual income less than Rs 400,000. Only 9.9\% respondents fall in this category. Category 2 was for individuals who has annual income from Rs 400,000 to Rs 800,000. $24.2 \%$ respondents fall in this category. Category 3 was for individuals who has annual income from Rs 800,000 to Rs $1,600,000.64 .3 \%$ respondents fall in this category. Only $2.2 \%$ respondents come in category 4 which is ranges from Rs 1,600,000 or greater.

\subsubsection{Descriptive Analyses}

As mentioned, there were 160 participants were male \& 22 were female. $75 \%$ Male given 
correct answers whereas out of 22 females $54 \%$ of females given the correct answers. 89.3\% Male showed high financial literacy, 5\% show mediate whereas 5\% show low financial literacy. $36.36 \%$ of females show high financial literacy, $27.27 \%$ show mediate whereas $36.36 \%$ show\% Low financial literacy. When asking about willingness to take risk $64.3 \%$ of individuals say that they will take risk whereas $13.7 \%$ were not agreeing to take a risk and $22 \%$ of people were in between. When asked about whether they go with steady returns with low risk or high return with high risk $63.7 \%$ shows they disagree means they will go with a high risk that will generate a high return. Whereas only $2.7 \%$ shows agree with the statement. $33.6 \%$ of people were in between. When asked about willingness to borrow money if think investment will generate positive outcome, $67 \%$ show they are agreed whereas only $8.8 \%$ said they won't borrow even if they will see investment can generate higher profit. When asked about the chance people can invest their saving for high returns, $62.4 \%$ of people were agreed whereas only $6.7 \%$ of people show disagree. If analyze risk tolerance, $34 \%$ of people show the ability to take risk whereas $22 \%$ of people show they will not take any risk others were in between. In overconfident, $65.9 \%$ state they have experienced investor, whereas only $1.1 \%$ say they have no experience and all others were in between.58.7\% people say that they rely on their own investment opinion rather someone else, whereas $1.1 \%$ disagree with that.58.8\% say that they can predict stock prices after they do some analyses, whereas $1.1 \%$ had no idea in prediction all others were in between.34.6\% people say that they consult with their family or colleague when investing, others show that they do not consult anyone in investing approximately $58.2 \% .61 \%$ people were agreed that they do compare the stock price of 52 high while making a purchase, whereas $39 \%$ state it as false.39.6\% say that they will sell their stock when prices will hit 52 weeks high whereas $60.4 \%$ were not agreed.62.6\% people say that they will not buy any stock which current prices are higher than last year, whereas $37.4 \%$ of people were not agreed. $41.2 \%$ people consider that prices are high when it hits 52 weeks high whereas $58.8 \%$ were not agreed.41.8\% people say that they will not invest in a company who has poor earning history whereas $58.2 \%$ say they will invest.76.4\% people say that they will prefer to buy stock who has good past performance because they think that good performance will continue in the future whereas $23.6 \%$ disagreed $.85 .7 \%$ consider stocks good if the performance of the firm is good over the past period whereas $14.3 \%$ reluctant to agree with that.87.4\% say that they trust on the reports, past performance about the stock on which my portfolio is composed off. Whereas $12.6 \%$ disagreed. When asked about if investors are concerned more on loss rather gain $75.8 \%$ were disagree means that they will prefer gain over loss hence showing less loss aversion whereas $24.2 \%$ agree with that statement. $80.8 \%$ disagreed with the given statement about whether they will invest or not when market performance is poor. $80.8 \%$ says they will invest even performance of the market is poor whereas $19.2 \%$ say that they will not increase their investment. We ask that is it more important to save capital than to earn a gain, $79.7 \%$ of people say that they will go for gain rather saving investment, whereas $20.3 \%$ agreed. When it comes to personality $79.7 \%$ says that they won't like suggestion and they do things in their way whereas $20.3 \%$ disagreed $.76 .9 \%$ people say that they become angry when forced to do the thing they are not agreed upon whereas $23.1 \%$ have disagreed with the statement. $85.7 \%$ people say that they have a strong opinion on what they do, whereas only $14.3 \%$ denied.86.8\% says that to get 
their right they will be standing for own self whereas $13.2 \%$ denied.88.5\% says that they work more efficiently rather wasting time whereas $11.5 \%$ were not agreed. When asking about how often you follow a systematic approach and methodical in life, 44.5\% show they are agreed whereas $55.5 \%$ show they don't follow.73.1\% says when they must do something tricky or difficult, they usually make plans to figure out things but $26.9 \%$ did not agree with the statement.73.6\% says that they arrange the things to smooth their life whereas $26.4 \%$ were not agreed.89\% says that they save their money so that they can invest to get some returns whereas $11 \%$ says they will not. $79.7 \%$ says that they keep a record of their money being spent whereas $20.3 \%$ say they don't keep record. $80.1 \%$ people say that they like to collect things whereas $19.9 \%$ says that they don't. $86.8 \%$ people say that they don't like to waste their money on something unproductive.66.5\% says that they have certain principles set and they take their life according to that. When asked about if fund A will decline in value what is the probability that you will sell your fund. $72.9 \%$ people say that they are uncertain, cannot say anything about that whereas 5\% says they will not sell \& $1.7 \%$ says that they will sell the fund A. When ask you to have invested equal amounts in mutual equity funds $\mathrm{A}, \mathrm{B}$, and $\mathrm{C}$. During the past 12 months, funds B and $\mathrm{C}$ have increased in value, whereas fund $\mathrm{A}$ has declined in value. What is the likelihood that you would sell your shares in fund A? 60.4\% of people say that they will not sell the fund A shares. Whereas $4.9 \%$ says that they will confirm sell the shares. $21.4 \%$ said they are likely to sell. When asked if Fund A, B \& C declined in value what is the probability that you will sell your share. $63.5 \%$ says they will sell the shares whereas, $4.4 \%$ says they will not. $8.3 \%$ were uncertain.

\subsection{Structural Equation Modeling}

To test the study hypothesis, we have used the structural equation model (SEM) whereas the testing has been gone through Smart PLS software. Moreover, to evaluate the indirect and direct effects of all the constructs the testing was done. The use of (SEM) structural equation model has been observed to be a foremost procedure that has been used below different regression models and methods (Barron \& Kenny, 1986). It used to evaluate the structural relationship between exogenous and endogenous variables. It includes factor analysis and multivariate analysis. Moreover, the equation of regression targets at explaining each construct to assess the cause and effect relationship while all the factors in the causal model could demonstrate their cause and effect at the exact time. Likewise, the idea of using this model ensures to apply the technique of bootstrapping which has been viewed as reasonable for both small and large sample size and does not require any kind of indirect effect (Hayes, 2013). To check all direct and indirect effects, a technique has been implemented which is known as bootstrapping (Shrout \& Bolger, 2002).

\subsection{Measurement of Outer Model}

The goal of measure of fit in the measurement model is to study about the reliability and validity of the instrument and to check its reliability and validity we perform the test of convergent validity and discriminant validity in software naming Smart PLS. 


\subsection{Composite Reliability}

Reliability implies stability of questionnaire outcomes. For the similar target population, at whatever points the questioner reutilize the questionnaire it will give a similar outcome. It demonstrates inside consistency \& repeatability of the survey is high. The primary measure for unwavering quality is to maintain a strategic distance from unfairness in research. In this manner, it tends to be improved by testing the pursuit procedure and investigation, as is done utilizing diverse research and examination techniques or different researchers. This also incorporates the dependability and legitimacy of the exploration.

Reliability of the measurement instruments was evaluated using composite reliability. All the values were above the normally used threshold value i.e. 0.70 . This is the accepted reliability value range. Estimation of reliability can be done by the degree of constancy that lies amongst various variables (Hair , 2010). Below is the table of composite reliability.

Table 4. Composite Reliability

\begin{tabular}{|l|l|}
\hline & Composite Reliability \\
\hline Anchoring & 0.643 \\
\hline Disposition Bias & 0.198 \\
\hline Financial Literacy & 1.000 \\
\hline Loss Aversion & 0.850 \\
\hline Obstinacy & 0.793 \\
\hline Orderliness & 0.527 \\
\hline Overconfidence & 0.635 \\
\hline Parsimony & 0.766 \\
\hline Representativeness & 0.690 \\
\hline Risk Tolerance & 0.658 \\
\hline Superego & 0.034 \\
\hline
\end{tabular}

\subsection{Factor Loadings Significant}

Table of descriptive statistics also mentioned loadings used in (CFA) confirmatory factor analysis. Construct with the loading of .5 are consider as strong loading variables whereas the constructs with the loading of below .5 are considered as less is better to be removed from the table.

\subsection{Convergent Validity}

Convergent validity is the level of agreement in at least two measures of a similar construct (Carmines and Zeller, 1979). Convergent validity was assessed by inspection of variance mined for each factor (Fornell and Larcker, 1981). Conferring to Fornell and Larcker (1981), if the variance extracted value is greater than 0.5 then convergent validity is established, and the result is drawn that the loadings are good but less than 0.5 are termed as less effective for the study. 
Following table displays the result.

Table 5. Cronbach's Alpha \& Composite Reliability

\begin{tabular}{|l|l|l|l|l|}
\hline & Cronbach's Alpha & rho_A & $\begin{array}{l}\text { Composite } \\
\text { Reliability }\end{array}$ & $\begin{array}{l}\text { Average Variance } \\
\text { Extracted (AVE) }\end{array}$ \\
\hline Anchoring & 0.427 & 0.651 & 0.643 & 0.445 \\
\hline Disposition Bias & -0.07 & 0.567 & 0.198 & 0.469 \\
\hline Financial Literacy & 1 & 1 & 1 & 1 \\
\hline Loss Aversion & 0.764 & 0.765 & 0.85 & 0.587 \\
\hline Obstinacy & 0.678 & 0.725 & 0.793 & 0.443 \\
\hline Orderliness & 0.308 & 0.565 & 0.527 & 0.427 \\
\hline Overconfidence & 0.2 & 0.857 & 0.635 & 0.465 \\
\hline Parsimony & 0.622 & 0.622 & 0.766 & 0.396 \\
\hline Representativeness & 0.425 & 0.424 & 0.69 & 0.365 \\
\hline Risk Tolerance & 0.249 & 0.789 & 0.658 & 0.597 \\
\hline Superego & -0.466 & 0.76 & 0.034 & 0.431 \\
\hline
\end{tabular}

\subsection{Discriminant Validity}

Discriminate validity can be defined as any single construct when differs from other constructs in the model (Carmines and Zeller, 1979). Discriminate validity results are satisfactory when the constructs are having an AVE loading more than 0.5 which means that a minimum $50 \%$ of the variance was taken by the construct (Chin, 1998). Discriminate validity is established if the elements which are in diagonal are significantly higher than those values in off-diagonal in the parallel rows and columns. Discriminant Validity tests are being conducted to see whether non-related ideas or measurements are unrelated or not. An effective assessment of discriminant legitimacy demonstrates that a trial of an idea is not exceptionally associated with different tests intended to quantify hypothetically various ideas. The table for Discriminant Validity is given below:

\begin{tabular}{|l|l|l|l|l|l|l|l|l|l|l|l|}
\hline & 1 & 2 & 3 & 4 & 5 & 6 & 7 & 8 & 9 & 10 & 11 \\
\hline Anchoring (1) & 0.667 & & & & & & & & & & \\
\hline Disposition Bias (2) & 0.600 & 0.685 & & & & & & & & & \\
\hline Financial Literacy (3) & 0.482 & 0.238 & 1.000 & & & & & & & & \\
\hline Loss Aversion (4) & 0.546 & 0.613 & 0.232 & 0.766 & & & & & & & \\
\hline Obstinacy (5) & -0.414 & -0.367 & -0.436 & -0.469 & 0.666 & & & & & & \\
\hline Orderliness (6) & -0.428 & -0.325 & -0.372 & -0.302 & 0.354 & 0.653 & & & & & \\
\hline Overconfidence (7) & 0.681 & 0.670 & 0.526 & 0.686 & -0.489 & -0.382 & 0.682 & & & & \\
\hline Parsimony (8) & -0.490 & -0.454 & -0.337 & -0.475 & 0.549 & 0.301 & -0.525 & 0.630 & & & \\
\hline Representativeness (9) & -0.526 & -0.536 & -0.328 & -0.543 & 0.409 & 0.430 & -0.616 & 0.536 & 0.604 & & \\
\hline Risk Tolerance (10) & 0.655 & 0.645 & 0.518 & 0.663 & -0.494 & -0.449 & 0.817 & -0.445 & -0.589 & 0.772 & \\
\hline Superego (11) & 0.711 & 0.638 & 0.503 & 0.559 & -0.440 & -0.442 & 0.659 & -0.494 & -0.610 & 0.689 & 0.656 \\
\hline
\end{tabular}




\subsection{Model Fit Measures}

The fitness of the model in SEM-PLS is defined by various measures such as standardised root-mean-square residual (SRMR), and the exact model fits like d_ULS and d_G, Normed Fit Index (NFI), and $\chi^{2}$ (Chi-square). The model fit measures consisting of the measured value of both saturated model as well as the estimated model is reported in the above Table. The saturated model assesses the correlation between all constructs. The estimated model, on the other hand, takes model structure into account and is based on the total effect scheme.

\begin{tabular}{|c|c|c|}
\hline \multicolumn{3}{|c|}{ Fit Summary } \\
\hline & Saturated Model & Estimated Model \\
\hline SRMR & 0.106 & 0.109 \\
\hline d_ULS & 10.545 & 11.164 \\
\hline d_G & 3.104 & 3.247 \\
\hline Chi-Square & 2705.976 & 2755.865 \\
\hline NFI & 0.415 & 0.404 \\
\hline
\end{tabular}

\section{$3.13 R$ Square}

As adjusted $\mathrm{R}$ square value is relatively low in financial literacy \& Loss aversion which is $0.325 \& 0.411$, respectively. Whereas Anchoring, Disposition bias, Overconfidence, representativeness\& risk tolerance has relatively higher adjusted $\mathrm{R}$ square. It explains how much variation in dependent variable is explained by an independent variable.

\begin{tabular}{|l|l|l|}
\hline & R Square & R Square Adjusted \\
\hline Anchoring & 0.555 & 0.543 \\
\hline Disposition Bias & 0.56 & 0.545 \\
\hline Financial Literacy & 0.325 & 0.31 \\
\hline Loss Aversion & 0.411 & 0.394 \\
\hline Overconfidence & 0.536 & 0.522 \\
\hline Representativeness & 0.47 & 0.455 \\
\hline Risk Tolerance & 0.74 & 0.726 \\
\hline
\end{tabular}

\subsection{Hypothesis Testing}

In PLS-SEM, bootstrapping is one of the key strides, which gives the data of constancy of factor guesstimate. Sub-tests are drawn everywhere from the first example including substitution, in this process (Hair, Matthews, Matthews, \& Sarstedt, 2017). Bootstrapping provides information about the stability of the coefficient estimate. In this process, many sub-samples are drawn from the original sample with replacement (Hair et al. 2016). After running the bootstrap routine, Smart PLS shows the t-values for structural model estimates derived from the bootstrapping procedure. The results of path coefficients for the entire hypothesis are shown in the following table. The $t$-value greater than $1.96(p<.005)$ shows 


\section{Macrothink}

Business and Economic Research

ISSN 2162-4860 2020, Vol. 10, No. 2

that the relationship is significant at 95\% confidence level $(\alpha=0.05)$. Path showing the significant relationship between measured and latent variables are significant or not. The path diagram showed in figure 2.

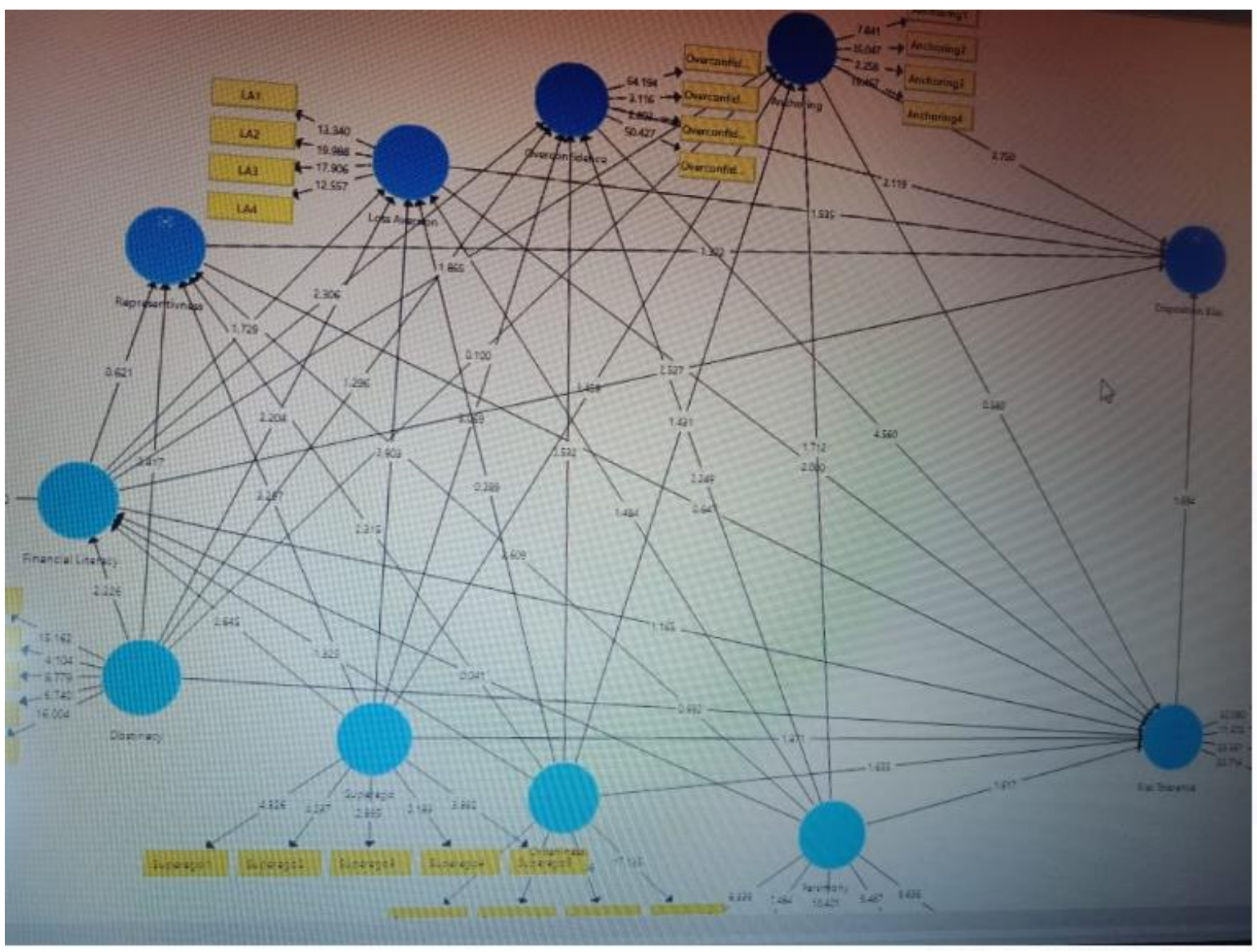

\begin{tabular}{|l|l|l|l|}
\hline & Sample Mean (M) & Standard Deviation (STDEV) & P Values \\
\hline Anchoring -> Disposition Bias & 0.233 & 0.079 & 0.003 \\
\hline Anchoring -> Risk Tolerance & 0.046 & 0.069 & 0.556 \\
\hline Financial Literacy -> Anchoring & 0.114 & 0.07 & 0.073 \\
\hline Financial Literacy -> Disposition Bias & -0.202 & 0.076 & 0.01 \\
\hline Financial Literacy -> Loss Aversion & -0.172 & 0.089 & 0.066 \\
\hline Financial Literacy -> Overconfidence & 0.179 & 0.083 & 0.017 \\
\hline Financial Literacy -> Representativeness & 0.059 & 0.074 & 0.502 \\
\hline Financial Literacy -> Risk Tolerance & 0.086 & 0.067 & 0.212 \\
\hline Loss Aversion -> Disposition Bias & 0.153 & 0.099 & 0.148 \\
\hline Loss Aversion -> Risk Tolerance & 0.176 & 0.079 & 0.038 \\
\hline Obstinacy -> Anchoring & -0.011 & 0.083 & 0.921 \\
\hline Obstinacy -> Financial Literacy & -0.244 & 0.11 & 0.028 \\
\hline Obstinacy -> Loss Aversion & -0.245 & 0.107 & 0.023 \\
\hline Obstinacy -> Overconfidence & -0.116 & 0.081 & 0.182 \\
\hline Obstinacy ->Representativeness & 0.048 & 0.086 & 0.656 \\
\hline
\end{tabular}




\begin{tabular}{|c|c|c|c|}
\hline Obstinacy -> Risk Tolerance & -0.063 & 0.066 & 0.36 \\
\hline Orderliness -> Anchoring & -0.103 & 0.072 & 0.168 \\
\hline Orderliness -> Financial Literacy & -0.144 & 0.107 & 0.197 \\
\hline Orderliness -> Loss Aversion & -0.031 & 0.082 & 0.697 \\
\hline Orderliness -> Overconfidence & -0.032 & 0.063 & 0.579 \\
\hline Orderliness ->Representativeness & 0.175 & 0.07 & 0.013 \\
\hline Orderliness -> Risk Tolerance & -0.085 & 0.052 & 0.123 \\
\hline Overconfidence -> Disposition Bias & 0.274 & 0.121 & 0.02 \\
\hline Overconfidence -> Risk Tolerance & 0.473 & 0.109 & 0 \\
\hline Parsimony -> Anchoring & -0.16 & 0.091 & 0.089 \\
\hline Parsimony -> Financial Literacy & 0 & 0.101 & 0.967 \\
\hline Parsimony $->$ Loss Aversion & -0.181 & 0.115 & 0.136 \\
\hline Parsimony -> Overconfidence & -0.196 & 0.084 & 0.024 \\
\hline Parsimony ->Representativeness & 0.282 & 0.078 & 0 \\
\hline Parsimony -> Risk Tolerance & 0.099 & 0.058 & 0.084 \\
\hline Representativeness -> Disposition Bias & -0.106 & 0.077 & 0.177 \\
\hline Representativeness $->$ Risk Tolerance & -0.046 & 0.066 & 0.521 \\
\hline Risk Tolerance -> Disposition Bias & 0.212 & 0.115 & 0.073 \\
\hline Superego -> Anchoring & 0.511 & 0.152 & 0.001 \\
\hline Superego -> Financial Literacy & 0.318 & 0.115 & 0.004 \\
\hline Superego -> Loss Aversion & 0.431 & 0.141 & 0.002 \\
\hline Superego -> Overconfidence & 0.399 & 0.127 & 0.002 \\
\hline Superego ->Representativeness & -0.395 & 0.119 & 0.001 \\
\hline Superego -> Risk Tolerance & 0.153 & 0.084 & 0.052 \\
\hline
\end{tabular}

Path coefficients indicate the following results.

1) Financial literacy has a significant impact on an investor's disposition bias. Since the P-value is less than 0.05 therefore, the null hypothesis rejected, and alternate hypothesis accepted. It means that individual with higher financial literacy will tend to show less disposition bias. Investor's with high financial literacy will not sell share solely based on price while going up or down.

2) Financial literacy has a significant impact on overconfidence since the P-value is less than 0.05 which reject the null hypothesis \& alternate hypothesis accept. Investor's with high financial literacy will tend to show high overconfidence in his ability to predict stock prices based on his financial knowledge.

3) No significant relationship found between financial literacy \& anchoring, loss aversion, representativeness\& risk tolerance since the P-value is greater than 0.05 . It means the null hypothesis accepted.

4) Anchoring has a significant relationship with disposition bias since the P-value is less than 0.05 . So, we reject the null hypothesis and accept the alternate hypothesis. Investors with high anchoring bias will tend to show more disposition bias because they will compare 
current prices with past data of stock earning. Therefore, when stock prices will go beyond or far from a reference point investor will use their previous study either to keep or drop the stock. Whereas anchoring has an insignificant relationship with risk tolerance since the P-value is greater than 0.05 which accepts the null hypothesis. Means that investor's with anchoring bias will be less risky because when they see prices are not consistent with past prices they will sell or buy share accordingly.

5) Loss aversion shows the insignificant relationship with disposition bias. P-value $>0.05$ indicates that when prices of a particular security will go down, investors will not hold it as they prefer to avoid losses than to gain. Whereas loss aversion exhibits a positive relationship with risk tolerance as P-values are greater than 0.05 which is 0.038 . Investors with loss aversion do not assume greater risk for holding security which falling below reference point.

6) The obstinacy which is a personality trait exhibits significant relationship with financial literacy \& loss aversion as P-value is less than 0.05 . As people with obstinacy trait tend to show less disposition bias due to their higher financial literacy. Because people with these personality traits hold on their opinion and does not change their action about a situation or events. Obstinacy also exhibits a positive relationship with loss aversion. Investors with obstinacy personality tend to show greater loss aversion because of their nature that they stick with their choices \& do not assume the risk.

7) Obstinacy has an insignificant relationship with overconfidence, Anchoring, Representativeness\& risk tolerance as Probability values is greater than 0.05 . Investor's with obstinacy trait will not be overconfidence, will not rely on past performance or continue to invest in stocks with good returns in the past \& they will not assume any given risk for investment.

8) Orderliness influences representativeness as P-value is 0.013 which is less than 0.05 \& rejects the null hypothesis. Investors with this personality trait will predict stock as it was in past because they will assume that good performance will continue. And they will avoid investing in companies' stocks which have poor past returns because they predict by comparing past. Orderliness shows an insignificant relationship with overconfidence, anchoring, loss aversion, risk tolerance \& financial literacy. Investor's with this personality trait will tend to show no cognitive bias (Overconfidence, Loss aversion \& Anchoring). Also, they won't be affected by financial literacy because they tend to do things in order and regular sequence. An individual with orderliness personality trait will be less risky because before they do their study or analysis about stock, they will not invest their money.

9) In this study, it is found that Parsimony has an impact on Overconfidence \&representativeness as $\mathrm{P}$-value is $<0.05$ which urges us to reject the null hypothesis \& accept the alternate hypothesis. People with Parsimony trait are unwillingness to spend their money. Due to this trait, they believe in their ability and use to make decisions rather investing in someone's advice. So, when the prices of stocks go down, they tend to sell shares in a poorly performing fund. Since investors with these traits don't want to spend money, they compare the prices of current stocks with previous data and predicts futures of the stocks. This gives them insight about security movement situation. Whereas no relationship was found with financial literacy, loss aversion, risk tolerance $\&$ anchoring. 
10) Representativeness shows insignificant impact with disposition bias \& risk tolerance as the P-value is greater than 0.05. Therefore, we can conclude that investors with this bias won't show disposition bias and they will not sell share when prices go up or hold when going down. Rather they will use previous studies to support the current situation of stock prices and decide about security.

11) Insignificant relationships were found between risk tolerance $\&$ disposition bias as $P$ values greater than 0.05 . It tells us that investor who can take a risk or have risk tolerance won't show disposition bias.

12) Superego has shown significant impact with cognitive bias (Anchoring, overconfidence, Loss aversion \&Representativeness) \& financial literacy. P values come to be less than 0.05 so we reject the null hypothesis and accept the alternate hypothesis. Investors with superego personality trait will tend to be more cognitive bias. It differentiates between right and wrong, and people make a judgment using it. Here investors will believe in their own abilities, will make a comparison between stock prices \& at the same time will try to avoid loss. It is known that investors who will have high financial literacy will exhibit this trait as this gives them a chance to study the movement of stock and manage their portfolio accordingly. Whereas the result reports an insignificant relationship with risk tolerance.

\begin{tabular}{|l|l|l|}
\hline & Standard Deviation (STDEV) & P Values \\
\hline Superego -> Financial Literacy -> Anchoring & 0.026 & 0.102 \\
\hline Financial Literacy -> Anchoring -> Disposition Bias & 0.017 & 0.082 \\
\hline Superego -> Anchoring -> Disposition Bias & 0.058 & 0.036 \\
\hline Obstinacy -> Financial Literacy -> Disposition Bias & 0.029 & 0.094 \\
\hline Superego -> Financial Literacy -> Disposition Bias & 0.036 & 0.061 \\
\hline Superego -> Overconfidence -> Disposition Bias & 0.068 & 0.096 \\
\hline Obstinacy -> Financial Literacy -> Overconfidence & 0.028 & 0.089 \\
\hline Superego -> Financial Literacy -> Overconfidence & 0.037 & 0.069 \\
\hline Financial Literacy -> Overconfidence -> Risk Tolerance & 0.046 & 0.035 \\
\hline Superego -> Financial Literacy -> Overconfidence -> Risk Tolerance & 0.019 & 0.077 \\
\hline Parsimony -> Overconfidence -> Risk Tolerance & 0.046 & 0.042 \\
\hline Superego -> Overconfidence -> Risk Tolerance & 0.069 & 0.005 \\
\hline
\end{tabular}

\subsection{Indirect Effect}

In this study, we try to see multiple mediations between variable if there is some sort of mediation. And we come up with the following results

1) Strong mediation effect found between Superegos, financial literacy and anchoring as $P$ values are less than 0.05 in both path coefficients and indirect effect. It is mean that financial literacy plays an important role in managing portfolio effectively. Investors with superego trait and anchoring bias can manage their portfolio. Strong mediation effect also found with Anchoring and disposition bias, as P Values for path coefficients and indirect effect are less than 0.05. Its means investors with anchoring bias will more likely not sell shares in 
poor-performing share. As they have anchoring bias, they will compare it with 52 weeks high and then decide their portfolio. Superego has strong mediation effect with overconfidence and disposition bias, as its values are less than 0.05 .

2) Parsimony has shown strong mediation effect with overconfidence \& risk tolerance. People with overconfidence bias will be more risk tolerates \& they will likely not to sell the share in poorly performing funds. Whereas partial mediation was found between parsimony with anchoring \& Representativeness.

3) Partial mediation was observed between obstinacy, overconfidence \& financial literacy. As P-value for path coefficients found to be less than 0.05 whereas in indirect effect P-value is founds to be greater than 0.05 . So, we can say that there is partial mediation. Investors with obstinacy personality trait restrict themselves with their own choices because they believe they trust their ability while investment.

4) Strong mediation indicated by obstinacy between financial literacy \& disposition bias. As P-value for path coefficient \& indirect effect is less than 0.05. Its mean that people with high financial literacy have ability to control while prices go down because they do show disposition bias.

\section{Discussions}

The results supported previous findings of Sadi et al (2011). Investors with high anchoring bias will tend to show more disposition bias because they will compare current prices with past data of stock earning. Therefore, when stock prices will go beyond or far from a reference point investor will use their previous study either to keep or drop the stock. The application of cognitive bias shows error in the process of thinking and processing information that is present around people. It is a method of gathering information and deducing meanings from it based on what they see (Lebowitz \& Akhtar, 2019; Morin, 2019).

In this study, we have found a significant relationship between financial literacy \& disposition. Investors who have greater financial knowledge will efficiently manage their portfolio. When studying cognitive bias, we have found that overconfidence \& anchoring shows a significant relationship with disposition bias as sig values is less than 0.05 . Overconfident investors will hold their investment while prices go up rather sold to gain profit. Also, investors will be anchoring bias can minimize their disposition because they compare it with the previous record and make decisions accordingly. We did not find any significant relationship between risk tolerance and disposition effect. Risk tolerance does not show any mediation between the variables. Superego trait of personality variable showed strong mediation with financial literacy, overconfidence, and anchoring. Moderate mediation was found between superego with representativeness \& loss aversion. Particularly personality has no significant effect on disposition but some of the traits showed mediation. Risk tolerance has shown partial mediation with overconfidence, loss aversion and disposition bias

\subsection{Hypothesis Assessment Summary}

\begin{tabular}{|l|l|l|l|l|}
\hline Hypothesis & $\begin{array}{l}\text { Standard Deviation } \\
\text { (STDEV) }\end{array}$ & $\begin{array}{l}\text { T } \\
\text { values }\end{array}$ & $\begin{array}{l}\text { P } \\
\text {-values }\end{array}$ & \begin{tabular}{l} 
Decision \\
\hline H1: Financial literacy has insignificant effect on Investor's disposition Bias.
\end{tabular} \\
\hline
\end{tabular}




\begin{tabular}{|c|c|c|c|c|}
\hline H2: Overconfidence has insignificant effect on Investor's disposition Bias. & 0.121 & 2.119 & 0.02 & Reject \\
\hline H3: Anchoring has insignificant effect on Investor's disposition Bias. & 0.079 & 2.750 & 0.003 & Reject \\
\hline $\begin{array}{l}\text { H4: Representativeness has insignificant effect on Investor's disposition } \\
\text { Bias. }\end{array}$ & 0.077 & 1.322 & 0.177 & Accept \\
\hline H5: Loss aversion has insignificant effect on Investor's disposition Bias. & 0.099 & 1.535 & 0.148 & Accept \\
\hline H6: Risk Tolerance has insignificant effect on Investor's disposition Bias. & 0.115 & 1.694 & 0.073 & Accept \\
\hline $\begin{array}{l}\text { H7: Over confidence has insignificant effect on Investor's disposition Bias } \\
\text { mediated by risk tolerance. }\end{array}$ & 0.109 & 4.560 & 0.00 & Reject \\
\hline $\begin{array}{l}\text { H8: Anchoring has insignificant effect on Investor's disposition Bias } \\
\text { mediated by risk tolerance. }\end{array}$ & 0.069 & 0.580 & 0.556 & Accept \\
\hline $\begin{array}{l}\text { H9: Representativeness has insignificant effect on Investor's disposition Bias } \\
\text { mediated by risk tolerance. }\end{array}$ & 0.066 & 0.647 & 0.521 & Accept \\
\hline $\begin{array}{l}\text { H10: Loss aversion has insignificant effect on Investor's disposition Bias } \\
\text { mediated by risk tolerance. }\end{array}$ & 0.079 & 2.00 & 0.038 & Reject \\
\hline $\begin{array}{l}\text { H11: Obstinacy has insignificant effect on Investor's disposition Bias } \\
\text { mediated by over confidence. }\end{array}$ & 0.081 & 1.296 & 0.182 & Accept \\
\hline $\begin{array}{l}\text { H12: Obstinacy has insignificant effect on Investor's disposition Bias } \\
\text { mediated by Anchoring. }\end{array}$ & 0.083 & 0.100 & 0.921 & Accept \\
\hline $\begin{array}{l}\text { H13: Obstinacy has insignificant effect on Investor's disposition Bias } \\
\text { mediated by representativeness. }\end{array}$ & 0.086 & 0.417 & 0.656 & Accept \\
\hline $\begin{array}{l}\text { H14: Obstinacy has insignificant effect on Investor's disposition Bias } \\
\text { mediated by Loss aversion. }\end{array}$ & 0.107 & 2.204 & 0.023 & Reject \\
\hline $\begin{array}{l}\text { H15: Orderliness has insignificant effect on Investor's disposition Bias } \\
\text { mediated by over confidence. }\end{array}$ & 0.063 & 0.532 & 0.579 & Accept \\
\hline $\begin{array}{l}\text { H16: Orderliness has insignificant effect on Investor's disposition Bias } \\
\text { mediated by Anchoring. }\end{array}$ & 0.072 & 1.431 & 0.168 & Accept \\
\hline $\begin{array}{l}\text { H17: Orderliness has insignificant effect on Investor's disposition Bias } \\
\text { mediated by Representativeness. }\end{array}$ & 0.07 & 2.315 & 0.013 & Reject \\
\hline $\begin{array}{l}\text { H18: Orderliness has insignificant effect on Investor's disposition Bias } \\
\text { mediated by loss aversion. }\end{array}$ & 0.082 & 0.389 & 0.697 & Accept \\
\hline $\begin{array}{l}\text { H19: Parsimony has insignificant effect on Investor's disposition Bias } \\
\text { mediated by over confidence. }\end{array}$ & 0.084 & 2.249 & 0.024 & Reject \\
\hline $\begin{array}{l}\text { H20: Parsimony has insignificant effect on Investor's disposition Bias } \\
\text { mediated by Anchoring. }\end{array}$ & 0.091 & 1.712 & 0.089 & Accept \\
\hline $\begin{array}{l}\text { H21: Parsimony has insignificant effect on Investor's disposition Bias } \\
\text { mediated by representativeness. }\end{array}$ & 0.078 & 3.609 & 0.000 & Reject \\
\hline $\begin{array}{l}\text { H22: Parsimony has insignificant effect on Investor's disposition Bias } \\
\text { mediated by loss aversion. }\end{array}$ & 0.115 & 1.484 & 0.136 & Accept \\
\hline $\begin{array}{l}\text { H23: Super ego has insignificant effect on Investor's disposition Bias } \\
\text { mediated by over confidence. }\end{array}$ & 0.127 & 3.069 & 0.002 & Reject \\
\hline $\begin{array}{l}\text { H24: Super ego has insignificant effect on Investor's disposition Bias } \\
\text { mediated by anchoring. }\end{array}$ & 0.152 & 3.459 & 0.001 & Reject \\
\hline H25: Super ego has insignificant effect on Investor's dispo & 0.119 & 3.297 & 0.001 & Reject \\
\hline
\end{tabular}




\begin{tabular}{|c|c|c|c|c|}
\hline mediated by representativeness. & & & & \\
\hline $\begin{array}{l}\text { H26: Super ego has insignificant effect on Investor's disposition Bias } \\
\text { mediated by loss aversion. }\end{array}$ & 0.141 & 2.903 & 0.002 & Reject \\
\hline $\begin{array}{l}\text { H27: Obstinacy has insignificant effect on Investor's disposition Bias } \\
\text { mediated by Financial literacy. }\end{array}$ & 0.11 & 2.226 & 0.028 & Reject \\
\hline $\begin{array}{l}\mathrm{H} 28 \text { : Superego has insignificant effect on investors disposition bias mediated } \\
\text { by risk tolerance. }\end{array}$ & 0.084 & 1.871 & 0.052 & Accept \\
\hline $\begin{array}{l}\mathrm{H} 29 \text { : Obstinacy has insignificant effect on investors disposition bias mediated } \\
\text { by risk tolerance. }\end{array}$ & 0.066 & 0.932 & 0.36 & Accept \\
\hline $\begin{array}{l}\text { H30: Super ego has insignificant effect on Investor's disposition Bias } \\
\text { mediated by Financial literacy. }\end{array}$ & 0.115 & 2.645 & 0.004 & Reject \\
\hline $\begin{array}{l}\text { H31: Financial literacy has insignificant effect on Investor's disposition Bias } \\
\text { mediated by risk tolerance. }\end{array}$ & 0.067 & 1.165 & 0.212 & Accept \\
\hline $\begin{array}{l}\text { H32: Financial literacy has insignificant effect on Investor's disposition Bias } \\
\text { mediated by over confidence. }\end{array}$ & 0.083 & 2.306 & 0.017 & Reject \\
\hline $\begin{array}{l}\text { H33: Financial literacy has insignificant effect on Investor's disposition Bias } \\
\text { mediated by Anchoring. }\end{array}$ & 0.07 & 1.865 & 0.073 & Accept \\
\hline $\begin{array}{l}\text { H34: Financial literacy has insignificant effect on Investor's disposition Bias } \\
\text { mediated by Representativeness. }\end{array}$ & 0.074 & 0.621 & 0.502 & Accept \\
\hline $\begin{array}{l}\text { H35: Financial literacy has insignificant effect on Investor's disposition Bias } \\
\text { mediated by loss aversion. }\end{array}$ & 0.089 & 1.729 & 0.066 & Accept \\
\hline $\begin{array}{l}\text { H36: Parsimony has insignificant effect on Investor's disposition Bias } \\
\text { mediated by Risk Tolerance. }\end{array}$ & 0.058 & 1.617 & 0.084 & Accept \\
\hline $\begin{array}{l}\text { H37: Orderliness has insignificant effect on Investor's disposition Bias } \\
\text { mediated by financial literacy. }\end{array}$ & 0.107 & 1.325 & 0.197 & Accept \\
\hline $\begin{array}{l}\text { H38: Parsimony has insignificant effect on Investor's disposition Bias } \\
\text { mediated by financial literacy. }\end{array}$ & 0.101 & 0.041 & 0.967 & Accept \\
\hline $\begin{array}{l}\text { H39: Orderliness has insignificant effect on investors disposition bias } \\
\text { mediated by risk tolerance. }\end{array}$ & 0.052 & 1.655 & 0.123 & Accept \\
\hline
\end{tabular}

\subsection{Conclusion}

Stock markets considered to be more volatile and help the firm to raise funds to achieve their objectives. We have shown that Pakistani investors are more subjected to behavioural biases in their decision because of the lack of financial literacy. They more inclined themselves towards short term gain and subject to disposition bias. To gauge the interest of investors we analyse all variables from different approaches. The number of risk-taking investors is quite low. The study aimed to investigate the effect of behavioural bias and financial literacy on investor's disposition bias with the mediating effect of risk and personality. This was achieved by administering the questionnaire to investors of stock markets from three brokerage houses in Karachi. The data was collected through 182 individuals from three brokerage houses in Karachi to achieve the purpose. 
As in previous studies mostly people tried to find the impact of financial literacy on investment decision or studied different biases in a different context without any mediating or moderating variable. In this study, we have taken personality and risk as a mediator and tried to check their effect of disposition bias. As said above Pakistani investors usually are short term investors who seek short term gains therefore, they fall easily in biases. As disposition showed by investors may take stock prices very above or low and create a tense situation in the market. Which investors cannot bear because it is very versatile also have a weak economy and political situation?

In Pakistan, since almost all members of the family are working so they try to save some of their money to meet future goals. To achieve this, many big investment houses have been opened all over the country which provided the opportunity to invest in stock markets, commodity, the debt market and many more. As mentioned, most of the population is not education therefore brokerage houses help to better manage their portfolio. This study would be beneficial for investors and brokerage houses as they will focus on financial literacy and try to reduce biases to enjoy gains.

\subsection{Limitations \& Future Research}

This research has been carried out to understand investor's cognitive bias and to cope with it. The data used in this research were solely primary and gathered through investment houses located in Karachi. Three investment houses used for this purpose and total participants were 182 who voluntarily contribute in this study. Future studies can be conducted using greater sample size and more brokerage house. As this study particularly done in Karachi, future studies can be done on other cities of Pakistan such as Lahore, Islamabad etc. Also, the future studies can be carried out using stock exchanges of difference countries.

\section{References}

Ahmad, M., \& Maochun, Z. (2019). Personality Traits and Investor Decisions. Asian Journal of Economics, Finance and Management, 16.

Aren, S., \& Zengin, A. N. (2016). Influence of Financial Literacy and Risk Perception on Choice of Investment. Procedia - Social and Behavioural Sciences, 8. https://doi.org/10.1016/j.sbspro.2016.11.047

Awais, M., Laber, M. F., Rasheed, N., \& Khursheed, A. (2016). Impact of financial literacy and investment experience on risk tolerance and investment decisions: empirical evidence from Pakistan. International Journal of Economics and Financial Issues, 6(1), 73-79.

Bailey, W., Kumar, A., \& Ng, D. (2006). Why do individual investors hold stocks and high expense funds instead of index funds? Johnson Graduate School of Management, Cornell University, Working Paper.

Baron, R. M., \& Kenny, D. A. (1986). The moderator-mediator variable distinction in social psychological research: Conceptual, strategic, and statistical considerations. Journal of Personality and Social Psychology, 51, 1173-1182.

https://doi.org/10.1037/0022-3514.51.6.1173 
Calvet, E., Campbell, J. Y., \& Sodini, P. (2006). Down or out: assessing the welfare costs of house hold investment mistakes. No. w12030, National Bureau of Economic Research. https://doi.org/10.3386/w12030

Campbell, J. Y. (2006). Household finance. Journal of Finance, 61(4), 1553-1604. https://doi.org/10.1111/j.1540-6261.2006.00883.x

Carmines, E. G., \& Zeller, R. A. (1979). Reliability and validity assessment (Vol. 17). Sage publications. https://doi.org/10.4135/9781412985642

Chin, W. W. (1998). The partial least squares approach to structural equation modelling. Modern methods for business research, 295(2), 295-336.

Chu \& Wang. (2017). Financial Literacy, Portfolio Choice, and Financial. Human Development and Family Studies Faculty. p. 37.

Fornell, C., \& Larcker, D. F. (1981). Structural equation models with unobservable variables and measurement error: Algebra and statistics. https://doi.org/10.2307/3150980

Hair, J. F., Black, W. C., \& Babin, B. J. (2010). Anderson. RE, 2010. Multivariate Data Analysis. New Jersey, Pearson Prentice Hall.

Hair Jr, J. F., Matthews, L. M., Matthews, R. L., \& Sarstedt, M. (2017). PLS-SEM or CB-SEM: updated guidelines on which method to use. International Journal of Multivariate Data Analysis, 1(2), 107-123. https://doi.org/10.1504/IJMDA.2017.087624

Hayes, A. F. (2013). Introduction to Mediation, Moderation, and Conditional Process Analysis: A Regression-Based Approach. New York, NY: The Guilford Press. Journal of Educational Measurement, 51(3), 335-337. https://doi.org/10.1111/jedm.12050

Javed, H., Bagh, T., \& Razzak, S. (2017). Herding Effects, Over Confidence, Availability Bias, and Representativeness as Behavioral Determinants of Perceived Investment Performance: An Empirical Evidence from Pakistan Stock Exchange (PSX). Journal of Global Economics, 13. https://doi.org/10.4172/2375-389.1000275

Jonsson, Sara., IL Soderberg dan Mats Wilhelmsson. (2017). An Investigation of the Impact of Financial Literacy, Risk Attitude, and Saving Motives on the Attenuation of Mutual Fund Investor Disposition Bias. Managerial Finance, 43(3), 282-298.

https://doi.org/10.1108/MF-10-2015-0269

Khan, M. Z. (2017). Impact of Availability Bias and Loss Aversion Bias on Investment Decision Making, Moderating Role of Risk Perception. Journal of Modern Developments in General Management \& Administration, 12 .

Kramer, M. M. (2016). Financial literacy, confidence and financial advice seeking. Journal of Economic Behaviour \& Organization, 20. https://doi.org/10.1016/j.jebo.2016.08.016

Kumar, Satish dan Nisha Goyal. (2015). Behavioural Biases in Investment Decision Making a Systematic Literature Review. Qualitative Research in Financial Markets, 7(1).

https://doi.org/10.1108/QRFM-07-2014-0022 


\section{$\triangle 1$ Macrothink}

Business and Economic Research ISSN 2162-4860 2020, Vol. 10, No. 2

Lebowitz, S., \& Akhtar, A. (2019, Oct). 60 cognitive biases that screw up everything we do. [Online] Available: https://www.businessinsider.com/cognitive-biases-2015-10

Leon \& Pringganingrum. (2018). The Effect of Financial Literacy, Risk Attitude, and Saving Motive on Bias Disposition Mutual Funds Investor in Indonesia Stock Exchange. Journal of Accounting and Financial Management, 16.

Lusardi, A., \& Mitchell, O. S. (2014). The economic importance of financial literacy: Theory and evidence. Journal of economic literature, 52(1), 5-44. https://doi.org/10.1257/jel.52.1.5

Marcin, R., Adam, S., \& Monika, C. (2015). Investors' expertise, personality traits and susceptibility to behavioural biases in the decision-making process. Contemporary Economics, 17.

Masomi, S. R., \& Ghayekhloo, S. (2011). Consequences of human behaviours' in Economic: The effects of behavioural factors in investment decision making at Tehran Stock Exchange. In 2010 International Conference on Business and Economics Research, Malaysia (Vol. 1).

Mouna, A., \& Anis, J. (2017). Financial literacy in Tunisia: Its determinants and its implications on investment behaviour. Research in International Business and Finance, 39, 568-577. https://doi.org/10.1016/j.ribaf.2016.09.018

Mouna, A., \& Anis, J. (2015). A study on small investors' sentiment, financial literacy, and stock returns: evidence for emerging market. International Journal of Accounting and Economics Studies, 3(1), 10-19. https://doi.org/10.14419/ijaes.v3i1.4098

Morin, A. (2019, Nov). How Cognitive Biases Influence How You Think and Act.

Mudrack, P. E. (2004). Job involvement, obsessive-compulsive personality traits, and workaholic behavioural tendencies. Journal of Organizational Change Management, 17(5), 490-508. https://doi.org/10.1108/09534810410554506

Odean, T. (1998b). Volume, volatility, price, and profit when all traders are above average. Journal of Finance, 53, 1887-1934. https://doi.org/10.1111/0022-1082.00078

Parveen, S., \& Siddiqui, M. A. (2018). Anchoring Heuristic, Disposition Effect and Overconfidence Bias in Investors: A Case of Pakistan Stock Exchange. Abasyn Journal of Social Sciences, 15.

Prosad, J. M., Kapoor, S., Sengupta, J., \& Roychoudhary, S. (2017). Overconfidence and Disposition Effect in Indian Equity Market: An Empirical Evidence. SAGE Publications, 19. https://doi.org/10.1177/0972150917726660

Rasquinha, A., Dunn, J. G., \& Dunn, J. C. (2014). Relationships between perfectionist strivings, perfectionistic concerns, and competitive sport level. Psychology of Sport and Exercise, 15(6), 659-667. https://doi.org/10.1016/j.psychsport.2014.07.008

Rostami, M., \& Dehaghani, Z. A. (2015). Impact of Behavioural Biases (overconfidence, ambiguity-aversion, and loss-aversion) on Investment Making Decision in Tehran Stock Exchange. Journal of scientific Research and development, 2(4), 60-64. 


\section{Macrothink}

Business and Economic Research ISSN 2162-4860 2020, Vol. 10, No. 2

Rubinstein, M., \& Leland, H. E. (1981). Replicating options with positions in stock and cash. Financial Analysts Journal, 37, 63-72. https://doi.org/10.2469/faj.v37.n4.63

Sadi, R., Asl, H. G., Rostami, M. R., Gholipour, A., \& Gholipour, F. (2011). Behavioural Finance: The Explanation of Investors' Personality and Perceptual Biases Effects on Financial Decisions. International Journal of Economics and Finance, 8. https://doi.org/10.5539/ijef.v3n5p234

Sarstedt, M., Hair, J. F., Ringle, C. M., Thiele, K. O., \& Gudergan, S. P. (2016). Estimation issues with PLS and CBSEM: Where the bias lies! Journal of Business Research, 69(10), 3998-4010. https://doi.org/10.1016/j.jbusres.2016.06.007

Shapira, Z., \& Venezia, I. (2001). Patterns of behaviour of professionally managed and independent investors. Journal of Banking \& Finance, 25(8), 1573-1587.

https://doi.org/10.1016/S0378-4266(00)00139-4

Shrout, P. E., \& Bolger, N. (2002). Mediation in experimental and non-experimental studies: new procedures and recommendations. Psychological methods, 7(4), 422.

https://doi.org/10.1037/1082-989X.7.4.422

Statman, M., Thorley, S., \&Vorkink, K. (2006). Investor overconfidence and trading volume. Review of Financial Studies, 19(4), 1531-1565. https://doi.org/10.1093/rfs/hhj032

Van Rooij, M., Lusardi, A., \& Alessie, R. (2011). Financial literacy and stock market participation. Journal of Financial Economics, 101(2), 449-472.

https://doi.org/10.1016/j.jfineco.2011.03.006

Vlaev, I., \& Elliott, A. (2013). Financial well-being components. Social Indicators Research, 118(3), 1103-1123. https://doi.org/10.1007/s11205-013-0462-0

Weber, M., \& Camerer, C. F. (1998). The disposition effect in securities trading: an experimental analysis. Journal of Economic Behaviour \& Organization, 33(2), 167-184.

https://doi.org/10.1016/S0167-2681(97)00089-9

\section{Copyright Disclaimer}

Copyright for this article is retained by the author(s), with first publication rights granted to the journal.

This is an open-access article distributed under the terms and conditions of the Creative Commons Attribution license (http://creativecommons.org/licenses/by/4.0/). 